\title{
Are disease duration and degree of functional impairment determinants of bone loss in rheumatoid arthritis?
}

\author{
ORLA S ALS, ANDERS GOTFREDSEN, BENTE J RIIS, AND \\ CLAUS CHRISTIANSEN
}

From the Department of Clinical Chemistry, Glostrup Hospital, University of Copenhagen, Denmark

SUMMARY One hundred and five patients with rheumatoid arthritis treated with a variety of: antirheumatic drugs, excepting glucocorticoids, were stratified according to the degree of $\vec{\varnothing}$ functional impairment (functional classes I to IV) and duration of the disease $(0-3$ years; $4-8$ o years; and $>8$ years). The variables investigated were distal forearm bone mineral content $\rightarrow$ (BMC), biochemical markers of bone formation: serum alkaline phosphatase and serum bone $\varsigma_{5}$ gamma-carboxyglutamic acid containing protein (BGP) and biochemical markers of bone $\vec{\nabla}$ resorption: fasting urinary calcium and fasting urinary hydroxyproline. Significant relationships $\vec{\bullet}$ were found between BMC and functional impairment and duration of the disease. Indices of or bone formation and bone resorption rose with increasing functional impairment, particularly those of bone resorption. It is concluded that disability induces osteopenia in rheumatoid arthritis by increasing the bone turnover with a more marked increased in resorption than in the formation processes. The effect of the disease duration is merely that of adding more years of $0^{\beth}$ functional impairment.

Key words: bone mineral content, bone turnover.

Patients with rheumatoid arthritis (RA) have osteopenia $^{1-4}$ and a disturbance of the calcium metabolism. ${ }^{5}$ The bone loss is pronounced in glucocorticoid treated patients ${ }^{134}$ but is also present in patients treated solely with non-steroidal antirheumatic drugs. ${ }^{134}$ It has not been established whether RA-associated osteopenia, if uninfluenced by glucocorticoids, is determined by the degree of functional impairment (disability, impaired ambulation, ${ }^{6-9}$ or by the duration of the disease. ${ }^{19}$ 10 Nor is it known whether the bone loss and the biochemical disturbances of calcium metabolism are proportional to these clinical variables.

In order to investigate these relationships we have evaluated the degree of functional impairment, measured the bone mineral content (BMC) in the distal forearms, and determined serum and urinary biochemical indices of the calcium metabolism in

Accepted for publication 8 January 1985.

Correspondence to Dr Orla S Als, Department of Clinical Chemistry, Glostrup Hospital, 2600 Glostrup, Denmark.
105 patients with definite or classical rheumatoid: arthritis.

\section{Patients and methods}

Bone mineral content (BMC) was measured by single photon absorptiometry $\left({ }^{125} \mathrm{I}\right)$. BMC is calcu-o lated as the mean of 12 scans, six on the distal part of each forearm, and expressed in arbitrary unitso (dimension: mass per unit length). ${ }^{11}$ The scanning is 0 performed rectilinearly with the first pass at the siten where the radius and the ulna are $8 \mathrm{~mm}$ apart, and $\sigma$ the remaining five passes are proximal to this. In this region the ratio of trabecular to cortical bone is about $0 \cdot 25 .^{12} \mathrm{BMC}$ was corrected for interferences? from varying amounts of fat in the soft tissues according to Rickers et al. ${ }^{13}$ The precision of the ${ }^{-}$ BMC measurement is $1.2 \%{ }^{14}$ In patients with $\widetilde{ }^{\vec{\Phi}}$ severe affection of one forearm only the contra- $\frac{\mathcal{Q}}{\mathrm{D}}$ lateral arm was measured. The BMC of the distal forearms has been shown to correlate well with the 
total body bone mineral in healthy subjects, and in patients with rheumatoid arthritis. ${ }^{2} 15$

Blood samples were taken in the morning after an overnight fast. Fasting urinary calcium and hydroxyproline relative to creatinine concentration (expressed in $\mathrm{mmol} / \mathrm{mmol}$ ) were obtained. Serum calcium, albumin, and creatinine, and urinary calcium and creatinine were measured on an SMA 6/60 autoanalyser, and the serum calcium was corrected to a constant serum albumin level. ${ }^{16}$ Serum phosphate was measured colorimetrically and serum alkaline phosphatase enzymatically according to Scandinavian recommendations. ${ }^{17}$ Fasting urinary hydroxyproline was determined by a spectrophotometric method, ${ }^{18}$ and serum bone gamma-carboxyglutamic acid containing protein (BGP) was analysed according to Catherwood. ${ }^{19}$

One hundred and five outpatients ( 29 men and 76 women) with definite or classical rheumatoid arthritis participated in the study. We included all the outpatients from the department of rheumatology and rehabilitation who fulfilled the inclusion criteria: at least six months of previous uniform treatment and no concurrent disease or treatment known to interfere with the calcium metabolism. For the purpose of the present work patients treated with glucocorticoids were left out. The patients were subdivided into three groups according to the antiinflammatory treatment: Group A: 29 patients, who were treated with gold salts in monthly doses of 50-200 mg. Group B: 61 patients, who were treated with penicillamine in daily doses of $300-750 \mathrm{mg}$. Group C: 15 patients, who were treated with other anti-RA drugs (cytostatics: $n=5$, antimalarials: $\mathrm{n}=7$, and non-steroidal anti-inflammatory drugs alone: $n=3$ ).

The degree of functional impairment was evaluated according to Steinbrocker et al., ${ }^{20}$ and the patients were thus divided into four functional classes (FC). Owing to the small number of patients in FCs III and IV, the data from these two classes were evaluated together. There were 37 patients in FC I, 50 patients in FC II, and 18 patients in FCs III + IV. The patients were also stratified into three groups according to the duration of the disease: $0-3$ years $(n=31) ; 4-8$ years $(n=34)$; and more than eight years $(n=40)$.

Table 1 shows some clinical data together with the BMC values.

All patients gave their written informed consent, and ethical approval was obtained from both local and national committees.

\section{STATISTICAL EVALUATION}

Since BMC and fasting urinary hydroxyproline are functions of sex and age, the values were calculated as a percentage of the normal mean values in corresponding sex and age groups. For the calculation of BMC relative to normal values the controls were divided according to sex and decades from 21 to 80 years of age. ${ }^{3}$ For the calculation of the urinary biochemical variables the controls were divided into three sex and age groups: men, women aged 21-50 years, and women aged $51-70$ years. ${ }^{3}$ The MannWhitney $U$ test for unpaired data was used in the statistical evaluation of the data.

\section{Results}

Patients in FC II and FC III + IV had a significantly longer duration of RA than patients in FC I (Table 2). Correspondingly, patients with a duration of RA longer than eight years had a significantly lower functional ability (higher functional class) than the patients with a disease duration of $0-3$ years (Table 3 ). No significant age differences were found between different strata (Tables 2 and 3). Patients in FC II and FC III + IV had significantly lower BMC than patients in FC I, whereas no significant difference in BMC was found between FC II and FC III + IV (Fig. 1A). Patients with a disease duration of four years or more had significantly lower BMC than those with a disease duration of less than four years (Fig. 1B). The alkaline phosphatase was significantly higher in FC II and FC III + IV than in FC I, and also significantly higher in FC III + IV than in FC II (Fig. 2). The level of serum alkaline phosphatase in patients with FC III + IV exceeded the upper limit of the normal reference interval for

Table 1 Clinical data and BMC (percentage of corresponding normal mean) in 105 patients with rheumatoid arthritis. Mean $\pm S D$

\begin{tabular}{llllr}
\hline Treatment & $\begin{array}{l}\text { Number } \\
(M / F)^{*}\end{array}$ & $\begin{array}{l}\text { Age } \\
\text { (years) }\end{array}$ & $\begin{array}{l}\text { Duration of disease } \\
\text { (years) }\end{array}$ & $\begin{array}{l}\text { Functional } \\
\text { class } \\
(\%)\end{array}$ \\
\hline Group A (gold) & $10 / 19$ & $52 \cdot 7 \pm 12 \cdot 4$ & $7 \cdot 6 \pm 7 \cdot 3$ & $1 \cdot 6 \pm 0 \cdot 7$ \\
Group B (penicillamine) & $15 / 46$ & $52 \cdot 7 \pm 11 \cdot 0$ & $10 \cdot 4 \pm 9 \cdot 1$ & $1 \cdot 9 \pm 0 \cdot 7$ \\
Group C (other drugs) & $4 / 11$ & $55 \cdot 0 \pm 11 \cdot 1$ & $10 \cdot 3 \pm 7 \cdot 8$ & $87 \cdot 1 \pm 19 \cdot 4$ \\
\hline
\end{tabular}

${ }^{*} \mathrm{M} / \mathrm{F}=$ male/female. 
Table 2 Age, duration of disease, serum calcium, and serum phosphate in 105 patients with rheumatoid arthritis stratified according to the degree of functional impairment. Mean $\pm S D$

\begin{tabular}{llllll}
\hline Functional class & $\begin{array}{l}\text { Number } \\
(M / F)\end{array}$ & $\begin{array}{l}\text { Age } \\
\text { (years) }\end{array}$ & $\begin{array}{l}\text { Duration of disease } \\
\text { (years) }\end{array}$ & $\begin{array}{l}\text { Serum calcium } \\
\text { (mmol/0.63 mmol albumin) }\end{array}$ & $\begin{array}{l}\text { Serum phosphate } \\
(\mathrm{mmol})\end{array}$ \\
\hline I & $12 / 25$ & $50 \cdot 7 \pm 12 \cdot 0$ & $7 \cdot 6 \pm 8 \cdot 1$ & $2 \cdot 39 \pm 0 \cdot 09$ & $1 \cdot 04 \pm 0 \cdot 14$ \\
II & $11 / 39$ & $54 \cdot 0 \pm 10 \cdot 7$ & $10 \cdot 2 \pm 8 \cdot 0^{*}$ & $2 \cdot 40 \pm 0 \cdot 10$ & $1 \cdot 09 \pm 0 \cdot 16^{*}$ \\
III + IV & $6 / 12$ & $54 \cdot 9 \pm 11 \cdot 5$ & $12 \cdot 3 \pm 10 \cdot 5 \dagger$ & $2 \cdot 44 \pm 0 \cdot 09^{\dagger}$ & $1 \cdot 10 \pm 0 \cdot 19$ \\
\hline
\end{tabular}

${ }^{*}$ Difference between functional classes I and II $(\mathrm{p}<0 \cdot 05)$.

†Difference between functional classes I and III + IV $(p<0 \cdot 05)$.

Table 3 Age, functional class, serum calcium, and serum phosphate in 105 patients with rheumatoid arthritis stratified into three groups according to the duration of RA. Mean $\pm S D$

\begin{tabular}{lllll}
\hline $\begin{array}{l}\text { Duration of disease } \\
\text { (years) }\end{array}$ & $\begin{array}{l}\text { Number } \\
(M / F)\end{array}$ & $\begin{array}{l}\text { Age } \\
\text { (years) }\end{array}$ & Functional class & $\begin{array}{l}\text { Serum calcium } \\
(\mathrm{mmol} / 0 \cdot 63 \mathrm{mmol} \text { albumin) }\end{array}$ \\
\hline $0-3$ & $10 / 21$ & $51 \cdot 8 \pm 11 \cdot 6$ & $1 \cdot 6 \pm 0 \cdot 7$ & $\begin{array}{l}\text { Serum phosphate } \\
(\mathrm{mmol} / \mathrm{l})\end{array}$ \\
$4-8$ & $9 / 25$ & $51 \cdot 2 \pm 12 \cdot 6$ & $1 \cdot 9 \pm 0 \cdot 7$ & $2 \cdot 41 \pm 0 \cdot 10$ \\
$>8$ & $10 / 30$ & $55 \cdot 5 \pm 9 \cdot 8$ & $2 \cdot 1 \pm 0 \cdot 8^{*}$ & $2 \cdot 41 \pm 0 \cdot 10$ \\
\hline
\end{tabular}

'Difference between groups of disease duration ' $0-3$ ' and ' $>8$ ' $(\mathrm{p}<0.01)$.
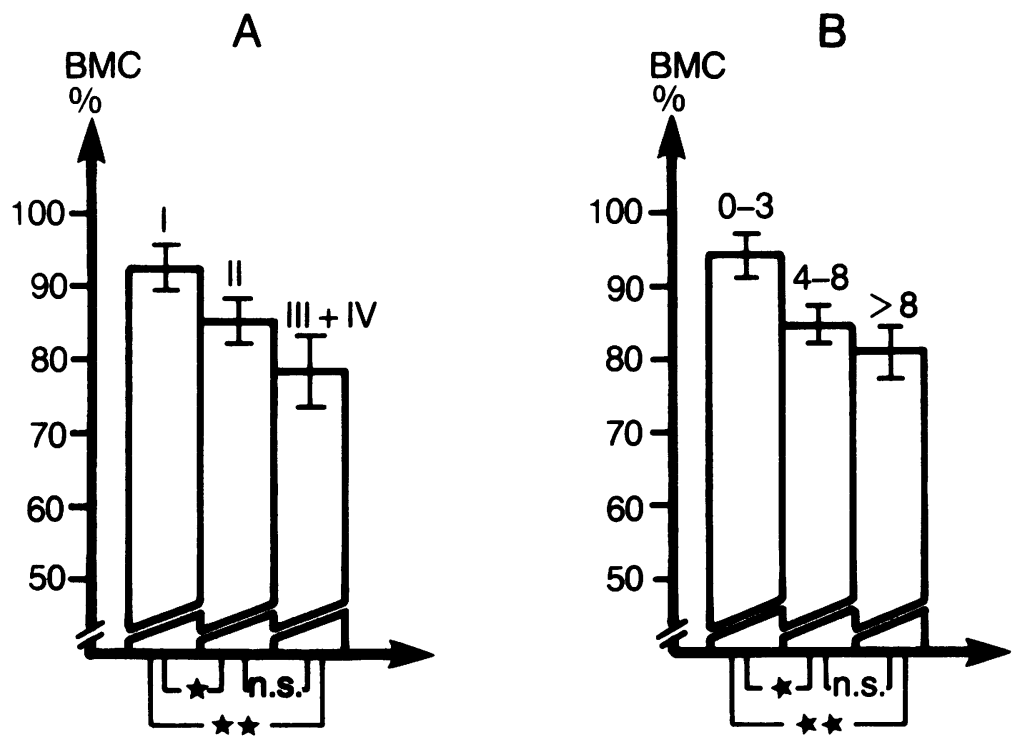

Fig. 1 Distal forearm bone mineral content $(B M C)$ in 105 patients with rheumatoid arthritis stratified $(A)$ according to the degree of functional impairment expressed as a functional class (FC $I$ to IV) and $(B)$ according to the duration of the disease $(0-3$ years, $4-8$ years, and $>8$ years). $B M C$ is expressed as a percentage of the corresponding normal. Mean values and standard errors of the mean are given in the figure. Statistical significance of differences by the Mann-Whitney $U$ test for unpaired observations: ${ }^{*} p<0.05,{ }^{* *} p<0.01$.

our routine laboratory $(260 \mathrm{U} / \mathrm{l})$. Serum BGP was significantly higher in patients in FC III + IV than in patients in FC I, but FC I and FC II and FC II and FC III + IV did not differ significantly with regard to serum BGP (Fig. 2). No significant differences were found between the different functional classes with regard to fasting urinary calcium. Fasting urinary hydroxyproline was significantly higher in FC III + IV than in both FC I and FC II, but there was no difference between FC I and FC II (Fig. 2). Serum calcium was significantly higher in FC III +
IV than in FC I and serum phosphate was signifi- N cantly higher in FC II than in FC I (Table 2).

Patients with a disease duration of four years or 0 more had significantly higher serum alkaline phos- $\frac{\mathscr{D}}{\mathscr{C}}$ phatase than those with a duration of RA of less $\stackrel{\infty}{+}$ than four years (Fig. 3). No significant differences $\square$ were found between the three different groupings of $O$ disease duration $(0-3$ years, $4-8$ years, and $>8 \stackrel{\mathbb{D}}{\circ}$ years) with regard to serum BGP, fasting urinary $\overrightarrow{\mathbb{D}}$ calcium, fasting urinary hydroxyproline, serum calcium, and serum phosphate (Fig. 3 and Table 3 ). 

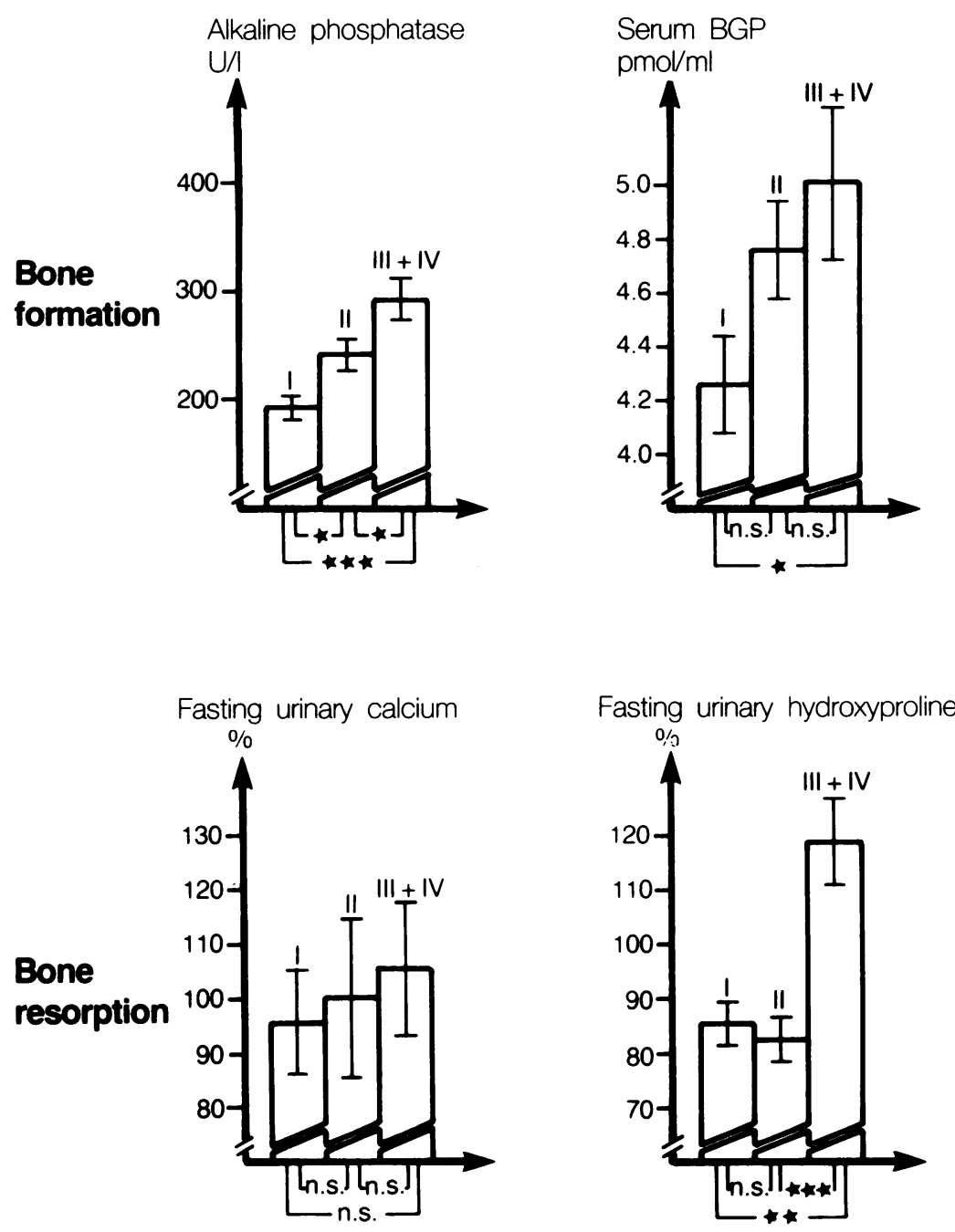

Fig. 2 Serum alkaline phosphatase, serum bone GLA protein (BGP), fasting urinary calcium, and fasting urinary hydroxyproline in 105 patients with rheumatoid arthritis stratified according to the degree of functional impairment expressed as a functional class (FC I to IV). The fasting urinary variables are expressed as a percentage of the corresponding normal. Mean values and standard errors of the mean are given in the figure. Statistical significance of differences by the Mann-Whitney $U$ test for unpaired observations: ${ }^{*} p<0.05,{ }^{* *} p<0.01$, and ${ }^{* * *} p<\cdot 001$.

\section{Discussion}

We deliberately excluded from the present calculations all patients who had received glucocorticoids. The data may thus be interpreted without having to consider the well known relationship between glucocorticoid treatment and decreased bone mass on the one hand ${ }^{4}$ and the relationship between the severity of rheumatoid arthritis and the probability of past or present glucocorticoid treatment on the other.

The pattern of BMC changes was much the same whether the patients were stratified according to functional class or duration of the disease (Fig. 1). A functional impairment corresponding to FC I or a disease duration of three years or less seems to imply a reduction in BMC from normal levels of less than $10 \%$. If the functional impairment increases (FC II) or the disease has lasted four years or more the BMC will be as low as $85 \%$. Progression from FC II to FC III or from less than eight to more than eight years of active RA does not seem to have any substantial influence on the BMC. It is therefore likely that the main part of the bone involvement takes place in the first three years of RA. The present data do not clarify which of the two, functional impairment or duration of RA, carries the principal load on the bone mass. However, since physical inactivity is a potent bone mass diminishing factor ${ }^{21}$ it is probable that the influence of disease 

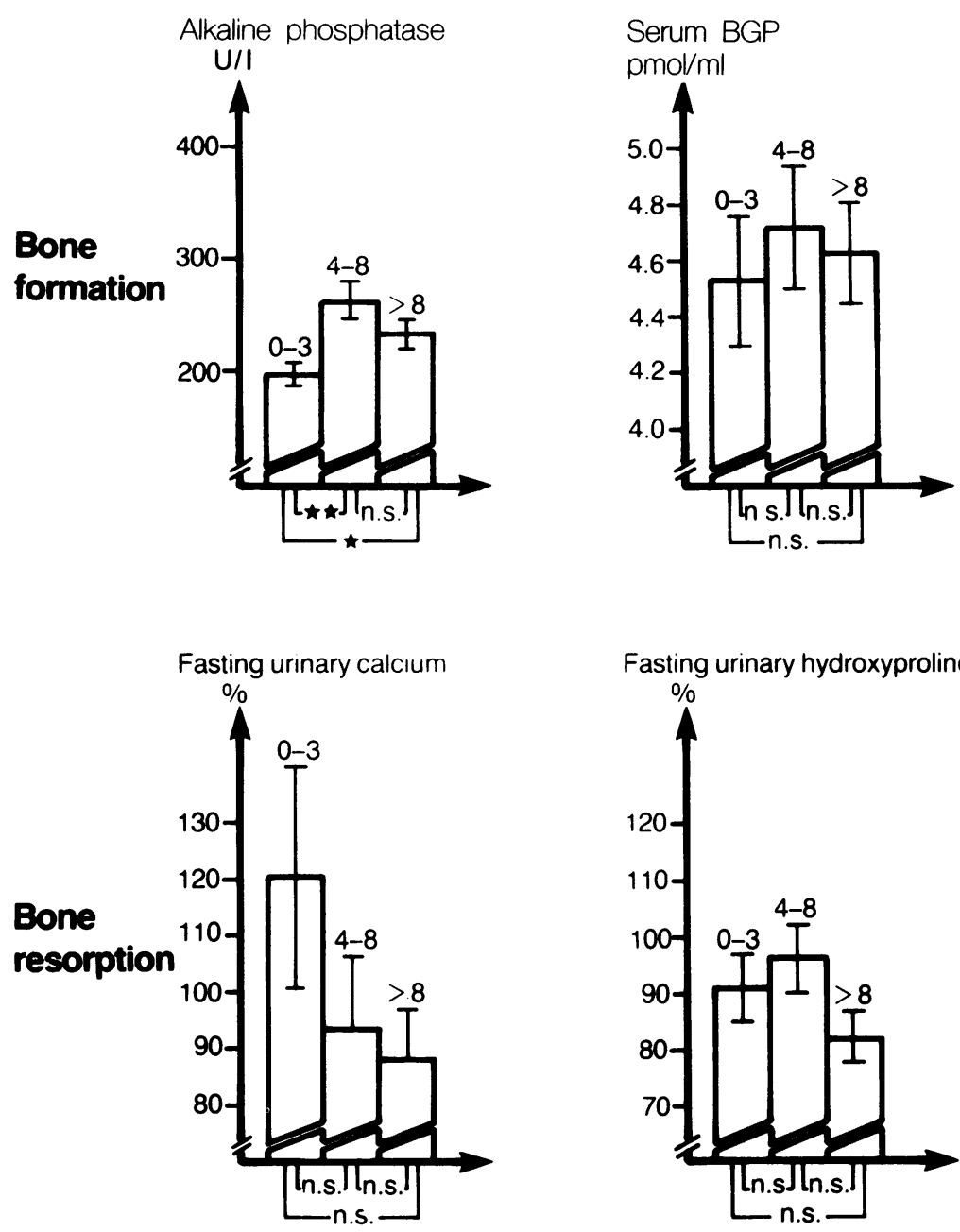

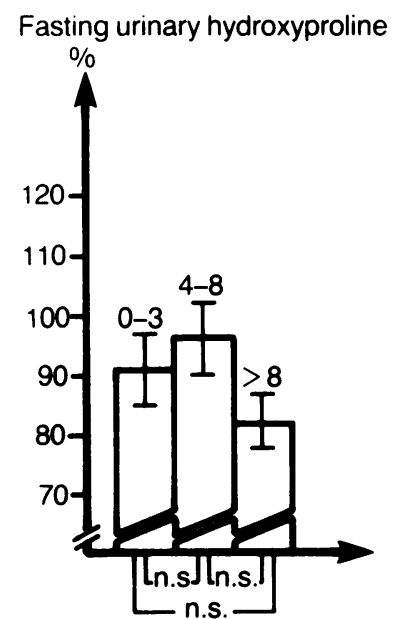

Fig. 3 Serum alkaline phosphatase, serum bone GLA protein $(B G P)$, fasting urinary calcium, and fasting urinary hydroxyproline in 105 patients with rheumatoid arthritis stratified according to the duration of the disease $(0-3$ years, $4-8$ years, and $>8$ years). The fasting urinary variables are expressed as a percentage of the corresponding normal. Mean values and standard errors of the mean are given in the figure. Statistical significance of differences by the Mann-Whitney $U$ test for unpaired observations: ${ }^{*} p<0.05,{ }^{* *} p<0.01$. duration is simply that of adding more years of inactivity (or functional impairment). This view is supported by the significant relationship between functional class and duration of the disease (Tables 2 and 3 ). This study agrees with a recent observation that disability and impaired ambulation are associated with an increased incidence of osteoporotic fractures in rheumatoid arthritis. ${ }^{22}$

Serum levels of alkaline phosphatase and BGP are biochemical markers of bone formation; ${ }^{23-26}$ and fasting urinary calcium and fasting urinary hydroxyproline are markers of bone resorption. ${ }^{26} 27$ Together, an increase in these indices would imply an increased turnover of bone tissue.

Our findings (Fig. 2) suggest that increased bone turnover in patients with a high degree of functional impairment is the cause of the reduction in BMC.
The clearly raised levels of alkaline phosphatase with increasing functional impairment may be the liver fraction as well as the bone fraction, ${ }^{28}$ and theo lack of a significant relationship between the functional class and the fasting urinary calcium may beo due to hypocalcaemia as found in some rheumaticn patients. ${ }^{3}$ Both fasting urinary hydroxyproline andN serum BGP were significantly higher in FC III + IV as compared with FC I, but the greater difference from FC I to FC III + IV in fasting urinary hydroxyproline (approximately $\mathbf{4 0 \%}$ ) than in serum BGP (approximately $20 \%$ ) suggests a preponderance of resorption over formation processes.

Stratification according to duration of the disease $\overrightarrow{0}$ (Fig. 3) produced no statistically significant observa- $\frac{?}{1}$ tions with regard to the biochemical calcium meta- $\varrho$ bolic indices, except for the serum alkaline phospha-? 
tase. This finding merely indicates that the duration is a less important determinant of the calcium metabolic disturbances in RA than is the degree of functional impairment.

We have earlier shown that groups of patients with RA have serum calcium levels lower than healthy controls and unaffected serum phosphate levels. ${ }^{3}$ However, neither duration of RA nor the functional impairment showed unequivocal relationships to these variables (Tables 2 and 3 ).

In conclusion, disability in rheumatoid arthritis induces osteopenia. A high degree of functional impairment implies a low bone mineral content. Disability brings about osteopenia by increasing the bone turnover, with a preponderance of resorption over formation processes. The greater part of the reduction in bone mass takes place during the first three years of the disease. However, the effect of a long duration of RA is mostly that of adding more years of disability.

We thank Professor L J Deftos and Dr B D Catherwood, Department of Medicine. University of California and San Diego VA Medical Center, La Jolla, California, USA, for determination of serum BGP; Dr Claus Hellesen, Department of Rheumatology and Rehabilitation, Glostrup Hospital, for permission to study his patients; and Niels-Erik Larsen, MSc, for determining the urinary hydroxyproline.

The study was supported by grants from Dagmar Marshalls Fond; Danish Rheumatism Association; Ferd. \& Ellen Hindsgauls Fond; and Fabrikant Einar Willumsens Mindelegat.

\section{References}

1 Reid D M, Kennedy N S J, Smith M A, Tothill P, Nuki G. Total body calcium in rheumatoid arthritis: effect of disease activity and corticosteroid treatment. $\mathrm{Br}$ Med $J$ 1982; 285: 330-2.

2 Als O S, Gotfredsen A, Christiansen C. Relationship between local and total bone mineral in patients with rheumatoid arthritis and normal subjects. Clin Rheumatol 1983; 2: 265-71.

3 Als O S, Christiansen C, Hellesen C. Prevalence of decreased bone mass in rheumatoid arthritis. Relation to antiinflammatory treatment. Clin Rheumatol 1984; 3: 201-8.

4 Als O S, Gotfredsen A, Christiansen C. The effect of glucocorticoids on bone mass in rheumatoid arthritis. Influence of menopausal state. Arthritis Rheum in press.

5 Cockel R, Kendall M, Becker J F, Hawkins C F. Serum biochemical values in rheumatoid disease. Ann Rheum Dis 1971; 30: 166-70.

6 Saville P D, Kharmosh O. Osteoporosis of rheumatoid arthritis: influence of age, sex and corticosteroids. Arthritis Rheum 1967; 10: $423-30$.

7 Oka M, Rekonen A, Kuikka J, Anttinen J. Bone mineral density in rheumatoid arthritis measured by the gamma transmission method. Scand J Rheumatol 1975; 4: 28-32.

8 Virtama P, Helelä T, Kalliomáki J L. Osteoporosis in rheumatoid arthritis. A follow-up study. Acta Rheumatol Scand 1968; 14: $276-84$.

9 Mueller M N. Effects of corticosteroids on bone mineral in rheumatoid arthritis and asthma. Am J Roentgenol 1976; 126: 1300 .
10 Kennedy A C. Smith D A. Buchanan W W, Anderson J B, Jasani M K. Bone loss in patients with rheumatoid arthritis. Scand J Rheumatol 1975; 4: 73-9.

11 Christiansen C. Rødbro P. Jensen H. Bone mineral content in the forearm measured by photon absorptiometry. Principles and reliability. Scand J Clin Lab Invest 1975; 35: 323-30.

12 Melsen F, Nielsen H E, Christensen P, Mosekilde Li, Mosekilde Le. Some relations between photon-absorptiometric and histomorphometric measurements of bone mass on the forearm. In: Mazess R B ed. Proceedings of the fourth international conference on bone measurements. NIH Publ. 80-1938, 1980: 45-50.

13 Rickers H, Balslev I, Foltved H, Rødbro P. Bone mineral content before and after intestinal bypass operation in obese patients. Acta Med Scand 1981; 209: 203-7.

14 Christiansen C, Rødbro P. Long-term reproducibility of bone mineral content measurements. Scand J Clin Lab Invest 1977; 37: 321-3.

15 Gotfredsen A. Als O S, Tjellesen L, Nilas L. Borg J, Christiansen C. Clinical applicability of in vivo estimation of total body bone mineral by dual photon absorptiometry. Measurements on normals and osteopenic patients. J Comput Assist Tomogr 1983; 7: 558-9.

16 Christiansen C, Naestoft J, Hvidberg E F, Larsen N-Ē, Petersen B. An easy procedure for in vivo estimation of protein binding and correction of elevated serum values induced by venous stasis. Clin Chim Acta 1975; 62: 65-71.

17 The Committee of Enzymes of the Scandinavian Society for Clinical Chemistry and Clinical Physiology. Recommended methods for the determination of four enzymes in blood. Scand J Clin Lab Invest 1974; 33: 291-306.

18 Pødenphant J. Larsen N-E. Christiansen C. An easy and reliable method for determination of fasting urinary hydroxyproline, an estimate of bone resorpotion. Clin Chim Acta 1984; 142: $145-8$.

19 Catherwood B D. Region specific radioimmunoassay (RIA) for human bone gamma-carboxyglutamic acid-containing protein (BGP) in blood and normal subjects. Calcif Tissue Int 1982; 34 (suppl): S29.

20 Steinbrocker O, Traeger C H, Batterman R C. Therapeutic criteria in rheumatoid arthritis. JAMA 1949; 140: 659-62.

21 Mazess R B, Whedon G D. Immobilization and bone. Calcif Tissue Int 1983; 35: 265-7.

22 Hooyman J R, Melton L J III, Nelson A M, O'Fallon W M, Riggs B L. Fractures after rheumatoid arthritis: a populationbased study. Arthritis Rheum in press.

23 Poser S, Cornish C, Kleerekoper M. Alkaline phosphatase and metabolic bone disorders. In: Avioli L V, Krane S M, eds. Metabolic bone disease. New York: Academic Press, 1977: 141-81.

24 Brown J P, Delmas P D, Malaval L, Edouard C. Chapuy M C, Meunier P J. Serum bone Gla protein: a specific marker for bone formation in postmenopausal osteoporosis. Lancet 1984; i: 1091-3.

25 Price P A, Williamson M D. Lothringer J W. Origin of the vitamin K-dependent bone protein found in plasma and its clearance by kidney and bone. J Biol Chem 1981; 256: 12760-6.

26 Lauffenburger T, Olah A J, Dambacher M A. Guncaga J, Lentner C, Haas H G. Bone remodeling and calcium metabolism: a correlated histomorphometric, calcium kinetic, and biochemical study in patients with osteoporosis and Paget's disease. Metabolism 1977; 26: 589-606.

27 Nordin B E C. Diagnostic procedures in disorders of calcium metabolism. Clin Endocrinol (Oxf) 1978; 8: 55-67.

28 Webb J, Whaley K, MacSween R N M, Nuki G, Dick W C, Buchanan W W. Liver disease in rheumatoid arthritis and Sjögren's syndrome. Ann Rheum Dis 1975; 34: 70-81. 